IFrom the Gastroenterological Research, Unit, Princess Margaret Chitdren's Molical Research Foundation, Perth, Western A istralia and the Department of Child Health, Medical School, University of Indonesia, Jakarta.

\title{
Microbial Contamination of the Gut; another Feature of Malnutrition *1,2.
}

\section{by}

MICHAEL GRACEY *, SUHARJONO, SUNOTO and DELYS E. STONE

\begin{abstract}
The microbial flora of the stomach and upper small intestine was studied in 21 malnourished Indonesian children with diarrhoea and comwareid with that found in 21 Australiam children of Caucasilan extraction with a variety of alimentary disorders.

In the Indonesian children there was marked microbial contamination of the upper gastrointestinal tract with a wide variety of microorganisms. In several patients there was significant overgrowth by Candida sp. and in several others large numbers of anaerobic bacteria were isolated.

It is suggested that these microbiological abnormalities are related to the pathogenesis of diarrhoea in children with malnutrition.

L. Supported by a grant from the Welcome Trust, London, England.

2. Reproduced with the kind permission of the Editor of Am. J. clin. Nutr. : 1170 (1973).

1. Adolph Basser Research Fellow of the Royal Australasian College of Physicians.
\end{abstract}




\section{Introduction}

As in other developing countries, nutritional deficiencies and diarrhoeal illnesses are common in children in Indonesia (Tumbelaka, 1968) and contribute largely to their high mortality rate. Enteric pathogens are common in the stools of these children but nothing is known of the microbial flora of their upper intestines and its possible contribution to their disease pattern.

This study documents the microbial flora of the stomach and upper intestine in a group of 21 children hospitalized in Jakarta mainly because of malnutrition and diarrhoea.

\section{Materials and methods}

The Dr. Tjipto Mangunkusumo Hospital is the main hospital in Jakarta and has a large children's ward staffed by members of the Depart. ment of Child Health, University of Indonesia. This ward serves the inäigent population of a large section of metropolitan Jakarta, a city of approximately 5 million people. Due to lack of space and facilities only severely ill patients are admitted. Large numbers are treated in the Outpatients Department.

There were 21 patients in this study; 11 boys and 10 girls. Their ages ranged from one week to 4 years; their mean age was 15 months and all except two patients were less than 2 years of age. Severe mallnutrition was evident in 13 patients; the nutritional status of the group is indicaited in Table 1. All pattients were suffering from diarrhoea and complicating illnesses were usual. These included bronchopneumonia (6), upper respiratory tract infections (3), purulent otitis media (3), vitamin A deficiency (4) and pulmonary tuberculosis (1). Pathogens were often found on stool microscopy, including Ascaris lumbricoides (9), and Trichomonas hominis (3): In thirteen patients antibiotic therapy was given; there was no difference found subsequently in microflora of patients receiving or not receiving antibiotics and they were considered together.

\section{Controls}

For ethical and practical reasons specimens of small-intestinal contents are not readily available from healthy, well-nourished children in Jakarta. In the present study, specimens taken from 21 Australian children of Caucasulan extraction were used for comparison. All except three of these children were less than two years of age; most had chronic diarrhoea and failure to thrive, and duodenal intubation was performed as part of their investigations. The underlying diseases in these children included coeliac disease (4), secondary lactose intolerance (5), giardiasis (3), cystic fibrosis (1), gastro-oesophageal reflux (1), Fasciola hepatica infestation (1), Menke's kinky hailr disease (1), Salmonellosis (1), and 4 cases of failure to thrive 
in whom a definitive diagnosis wás not reached.

\section{Collection of Specimens :}

Specimens of small intestinal contents were obtained by pernasal intubation. Following at least four hours fast, a sterile Levin's red rubber tube was manipulated into the duodenum 'blind' as adequate radiological equipment was not available. Repeated aspiration was done and specimens were taken first from the stomach and the duodenum. Throat swabs were also taken. Duodenal aspirates were discarded until the fluid was clear, bile stained and the $\mathrm{pH}$ was greater than 6. All specimens $(0.2 \mathrm{ml})$ were collected directly into $2 \mathrm{ml}$ of transport medium (1.8ml of gliucose and $0.2 \mathrm{ml}$ of glycerol) oni ice and then immediately deepfrozen. The deep-frozen specimens were transported on dry ice personally by air to the Unit in Perth where the microbiological studies were done.

\section{Microbiological techniques}

Serial, tenfold dilutions of specimens were done before they were plated on the following media; horse blood agar (routine and anoxic), MacConkey agar, Sabouraud dextrose agar and the medium of de Man, Rogosa and Sharpe. Rigid anaerobic conditions were achieved by repeated evacuation of the anaerobic jar and replacement by dry hydrogen. Ten per cent carbon dioxide was provided in the jar during the incubation period by a culture of coliforms growing in glucose broth in an open ended container. The growth of a pure culture of the strict' anaerobe Clostridium tetani, in each jar was used as a check of anaerobiosis. Blood agar plates used immediately after pouring or stored anaerobically and plates containing de Man, Rogosa and Sharpe's medium were incubated under rigid anaerobic condilitions at $37^{\circ} \mathrm{C}$ for up to six days. Organisms isolated on anaerobic plates were then subcultured onto the same two media under aerobic conditions to exclude facultative anaerobes.

Salmonellae were sought by the following method: $0.1 \mathrm{ml}$ of each specimen was incubated in strontium chloride and strontium selenite enrichment broth (Iveson et al., 1969) overnight at $37^{\circ} \mathrm{C}$. Inoculants from this broth were then plated onito Hektoen enteric agar (King and Metzger, 1968) and incubated overnight at $37^{\circ} \mathrm{C}$, non lactose-fermenting colonies picked from these plates were then subcultured into Glissuda tubes (Iveson et al., 1969) and incubated at $37^{\circ} \mathrm{C}$ for 24 hours. Those tubes showing colour reactions characteristic of Salmonella sp. and Shigella $s p$. were further identified using standard serological and biochemical methods.

When calculating colony counts appropriate corrections were made for the dlilution of specimens during collection. 
Because of the log. normal distribution of intestinal bacterial counts (Best, 1970) a standard method of logarithmic transformation of the total counts was used to achieve statistical comparison between the Indonesian children and the controls (Sokal and Rohlf, 1969). This method allows lower and upper limits of this distribution to be obtained. Statistical results were obtained at the $95 \%$ confidence level.

\section{Results}

Large numbers (105 per $\mathrm{ml}$ or more) of organisms were isolated from the gastric contents of all except one patient. This is in marked contrast to the control group in which all specimens were relatively sterile and nearly always contained less than $10^{4}$ organisms per $\mathrm{ml}$.

A wide range of organisms were found: Most specimens had large numbers of Gram positive and catalase positive cocci, Enterobacteria, Strep'tococci and Candida. Faecaltype bacteria were found in 9 specimens and Corynebacteria in 6.

Anaerobes were isolated from none of the controls; but were present in the gastric contents of 7 of the Indonesian children.

In the controls, five specimens were sterile and the small intestinal flora was always less than $10^{5}$ organisms per $\mathrm{ml}$; the arithmetical mean population was $7.4 \times 10^{8}$ per mi.

Satisfactory small intestinal aspirates were obtained from 20 of the
21. Indonesian patients. In only two of these patients were the small intestinal aspirates sterile. In each of the other patients, more than $10^{4}$ organisms per $\mathrm{ml}$.were found and in 14 out of the 20 specimens the count was $10^{5}$ per $\mathrm{ml}$ or more.

The arithmetical mean microbial count was $7.8^{\circ} \times 10^{7}$ per ml which is much greater than in the controls. Specimens from most patients grew Gram-positive and catalase-positive cocci, Enterobacteria and Streptococci; Candida were isolated in half of the patients, faecal-type bacteria in 6 and Corynebacteria in 2. In marked contrast to the controls, anaerobes were isolated in 7 out of the 20 Indionesian children, in 5 cases anaerobes were present in larger numbers than 105 per mil, Salmonella paratyphi $B$ was found in two patients and Shigella sp. in two others.

When examined statistically, the re was a very significant increase in the microflora in the Indonesian children compared with controls in all except one microbiological category (see Table 2). There was no significant difference in the numbers of faecal bacteria (Strep Iaecalis and lactobacilli) between the two groups, largely because of the small number of isolations in each group; 4 in the controls and six in the patients, although four patients had counts in excess of $10^{4}$ per $\mathrm{ml}$.

The extensive variety of organisms found in the small intesitinal con- 
tents of the Indonesian subjects is indicated in Table 3 .

\section{Discussion}

This study indicates that gross microbial contamination of the upper gastrointestinal tract occurred commonly in a groulp of malnourished Indonesian children with diarrhoea, in comparison with a control group of relatively wellnourished Australian children of Caucasian descent.

In health, the gastric contentis of fasting subjects are relatively sterile; this was found in the control group. By contrast, more than $\mathbf{1 0}^{4}$ organisms per $\mathrm{ml}$ were found in all except one of the 21 patients; in 16 subjecti heavy microbial contamination occurred, ife. more than $10^{6}$ organisms per $\mathrm{ml}$. In six subjects the degree of contamination was quite remarkable and exceeded $10^{8}$ organisms per ml. The explanation for these findings is not clear. While the $\mathrm{pH}$ of the gastric contents was within the normal range, nothing is known of the rate of fasting acid secretion in these children. Perhaps this is impaired, thus preventing the normal bactericidal effect of gastric contents and leading to bacterial contamination, as it does in patients with achlorhydria (Drasar et al., 1969). Respiratory tract infections were common in these 21 patients and it is possible that the repeated ingestion of viable organisms expelled from the respiratory tree contributed to the presence of large num- bers of bacteria in the gastric contents of these children. These possibilities are at present under investigation.

The small intestinal flora in the control group was sparse. Less than $10^{4}$ organisms per $\mathrm{ml}$ were usually isolated and in no patient was more than $10^{5}$ organisms per $\mathrm{ml}$ found. These findings resemble those found in similar patients in Britain (Drasar and Shiner, 1969). Microbial contamination of the upper small intestine occurred in most of the Indonesian patients. In 16 out of the 20 specimens studied $10^{5}$ or more organisms per $\mathrm{ml}$ were found and in 8 cases the count exceeded $10^{\circ}$ per $\mathrm{ml}$.

In both gastric and small intestinal aspirates a wide variety of organisms was isolated. These included Grampositive cocci, Escherichia coli and other enterobacteria such as Klebsiella sp., Pseudomonas isp., Salmonella paratyphi $B$ and Shigella s'p. In six cases significant numbers of anaerobes were isolated; these included Bifidobacteria, Pcptostreptococci and Bacteroides. Candida were present in signifinant numbers in 8 patients, 6 of whom were receiving antibiotic therapy.

Few studies are available of the small intestinal microflora of children with malnutrition. In Guatemala, Dammin $(1964,1965)$ found excessive numbers of bacteria in specimen taken from jejunal contents of malnourished children with diarrhoea, but that the flora was nor- 
mal in malnourished children without diarrhoea. The organisms he isolated were not recognized bacterial pathogens but nevertheless he suggested that they might contribute to diarrhoeal illnesses in such children. Unfortunately, his studies were done on necropisy material taken some hours after death, so their validity is rather doubtful. Some more recent situdies have confirmed that bacterial contamination of the upper gut occurs in vivo in patients with malnutrition. Gorbach et all. (1969, 1970) found significant overgrowth mostly by coliforms, of the upper gut in acult Bengalis with tropical sprue and a rapid drop in the numbers of organisms during recovery. A generalized and marked, increase in oraltype and faecal-type aerobes was found in the small intestinal contents of 18 Australian aboriginal infants and children with malnutrition and chronic diarrhoea (Gracey and Stone, 1972). Mata et al. (1972) have found marked bacterial overgrowth in the upper gastrointestinal tract in malnourished Guatemalan children with or without diarrhoea and a decrease in numbers of organisms during nutritional rehabilitation. On the other hand, James et al. (1972) found few cases of bacterial overgrowth by $\mathrm{E}$. coli, enterococci, bacteroides and Bifidobacteria in a group of malnourished Jamaican children. There was no qualitative or quantitative difference between those with and without diarrhiea and following itreatment. These differences are not easily explaimed; the marked discrepancy between the Jamaican study and the present one is probably not due simply to technical differences as there was close agreement between studies in control subjects in each study. Perhalps the severity of diarrhoea, the presence of respiratory tract infections and the unsanitary conditions under which the Indonesian patients live contribute to this difference. Certainly, further studies of patients with diarrhoeal illnesses in tropical areas seem warranted.

The pathogenetic significance of bacterial contamination of the upper gut in such individuals with malnutrition is far from clear.

Gorbach's work showed that E. coli isolated from his Bengali subjects were capable of producing an enterotoxin, yet James et al. (1972) found no such effect. Some preliminary results from this laboratory (Elliot et al., 1972) suggest that bacteria isolated from malnourished patients, while not considered enteropathogenic in the usual sense, are capable of interfering with the intestinal absorption of small, watersoluble molecules. It seems possible that bacterial contamination of the upper gastro-intestinal tract is yet another manifestation of the complex synergism of nutrition and infection so characteritistic of malnutrition (Scrimshaw et al., 1968). 
TABLE 1 : Nutritional Status of 21 Indonesian Children with diarrhoea

\begin{tabular}{|c|c|c|c|}
\hline \multirow{2}{*}{ Nutritional status } & \multicolumn{2}{|c|}{ Definition } & \multirow{2}{*}{ Number of patients } \\
\hline & $\%$ of SWFA & oedema & \\
\hline Normal & $>80$ & no & 3 \\
\hline Underweight & $60-80$ & no & 5 \\
\hline Kwashiorkor & $60-80$ & yes & 6 \\
\hline Marasmus **) & $<60$ & no & 1 \\
\hline Marasmic kwashiorkor & $<60$ & yes & 6 \\
\hline
\end{tabular}

*) As sugested by Welcome Working Party (Editorial Lancet, 1970). Weight expressed as a percentage of standard weight for age (SWFA) compared with the 50th centile of the Harvard standards (Jelliffe, 1966).

*) This patient wes a low-birth-weight; premature neonate. 
TABLE 2 : Small intestinal microflora in 21 Australian children and 20 malnontished Indonesian children. Restits indicate population on various species and totat flora expressed is the log of 10 the mean viable colony count per $m l$ of specimens *)

\begin{tabular}{|c|c|c|c|c|c|c|c|c|}
\hline & & $\begin{array}{c}\text { Gram-positive } \\
\text { bacteria }\end{array}$ & Candida & $\begin{array}{l}\text { Entero- } \\
\text { bacteria }\end{array}$ & $\begin{array}{c}\text { Faecal } \\
\text { bacteria }\end{array}$ & $\begin{array}{l}\text { Total } \\
\text { Aerobes }\end{array}$ & Anaerobes & $\begin{array}{c}\text { Total } \\
\text { Organisms }\end{array}$ \\
\hline$\ldots$ & $I_{1}$ & 1.7 & 0.1 & 0.5 & 0.1 & 2.2 & 1.9. & 2.2 \\
\hline$\therefore$ & Mean & 2.3 & 0.5 & 1.1 & 0.6 & 2.8 & 0.1 & 2.8 \\
\hline \multirow[t]{2}{*}{ 'Controls' } & $\mathrm{L}_{2}$ & 2.9 & 0.9 & 1.7 & 1.1 & 3.4 & 0.3 & 3.1 \\
\hline & $\begin{array}{c}\text { Range } \\
\text { (arithmetical) }\end{array}$ & $0-4 \times 104$ & $0-1.3 \times 103$ & $0-3.2 \times 104$ & $0-2 \times 103$ & $0-5 \times 104$ & $0-7.9 \times 10^{2}$ & $0-5 \times 10$ \\
\hline & $L_{1}$ & 3.8 & 0.7 & 3.7 & 0.6 & 4.6 & 0.9 & 4.6 \\
\hline \multirow{2}{*}{$\begin{array}{l}\text { Indonestan } \\
\text { patients }\end{array}$} & Mean & 4.8 & 2.4 & 4.5 & 1.4 & 5.5 & 2.0 & 5.5 \\
\hline & $\mathbf{L}_{2}$ & 5.8 & 4.1 & 5.3 & 2.2 & 6.4 & 3.1 & 6.4 \\
\hline \multirow[t]{2}{*}{$\therefore \ldots .: \vdots$} & $\begin{array}{c}\text { Range } \\
\text { (arithmetical) }\end{array}$ & $0-1 \times 108$ & $0-2 \times 106$ & $0-1.3 \times 109$ & $0-4 \times 106$ & $0-1.3 \times 100$ & $0-1.3 \times 108$ & $0-1.3 \times 10^{5}$ \\
\hline & $P$ & $<0.005$ & $<0.025$ & $<0.0005$ & $\begin{aligned} 0.3 & <\mathrm{p} \\
& <0.35\end{aligned}$ & $<0.0025$ & $<0.05$ & $<0.0025$ \\
\hline
\end{tabular}

*) Upper and lower limits of these populations determined at the $95 \%$ confidence level using a standard method of $10-$ garithmic transformation. 
TABLE 3: Bacterial contamination of the upper intestinal in 20 Indonesian children with malnutrotion and diarrhoea.

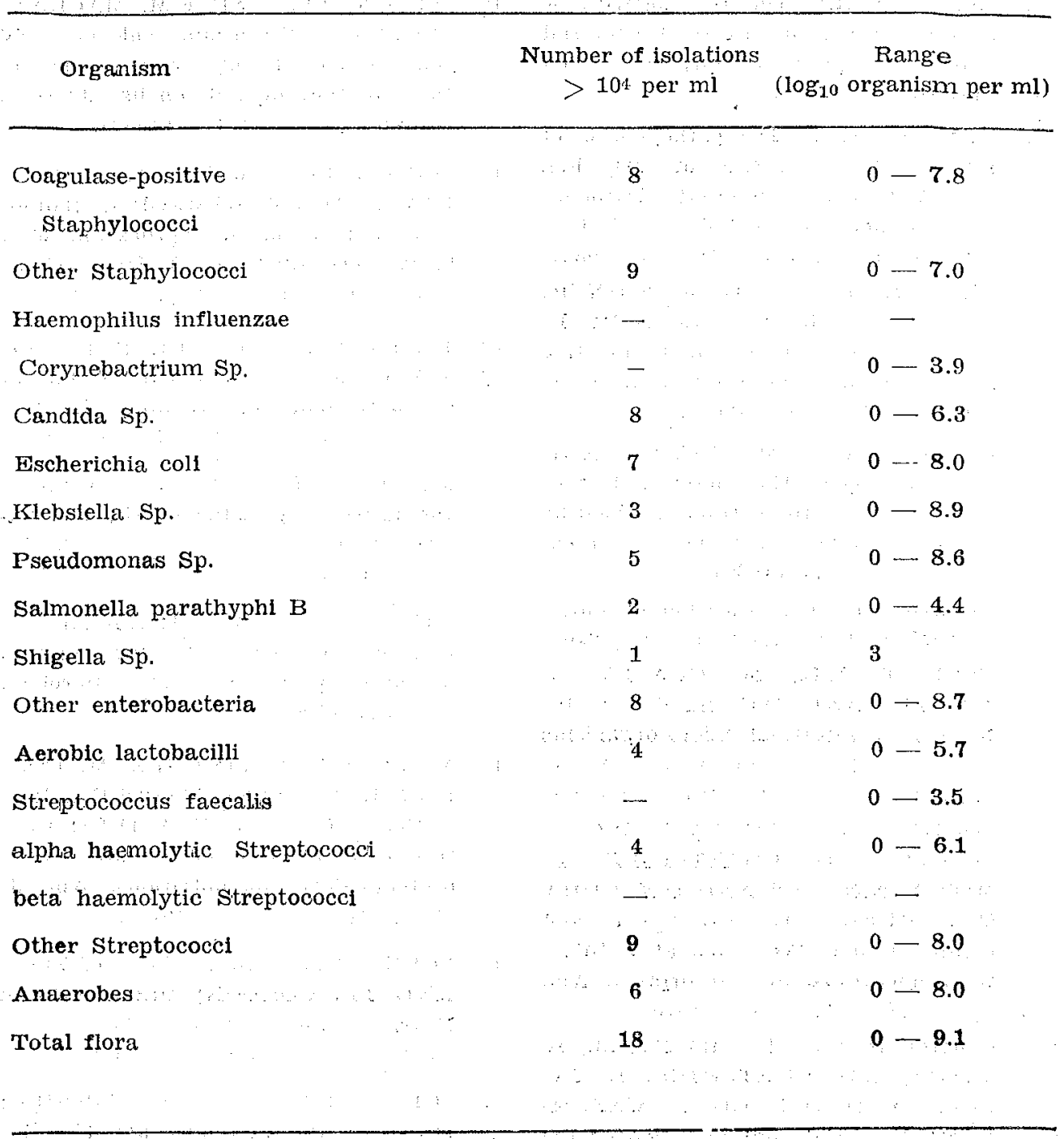




\section{REFERENCES}

1. BEST, W.R.: On the logarithmic transformation of intestinal bacterial counts. Am. J. Clin. Nutr. 23 : 1608 (1970).

2. DAMMIN, G.J.: The pathogenesis of acute diarrheal disease in early life. Bull. W.H.O. 31 : 29 (1964). Pathoge. nesis of acute clinical diarrheal disease. Federation Proc. 24 : 35 (1965).

3. DRASAR, B.S., AND M. SHINER: Studies on the intestinal flora. Part II. Bacterial flora of the small intestine in patients with gastrointestinal disorders. Gut 10 : 812 (1969).

4. DRASAR, B.S., M. SHINER AND G.M. MeLEOD: The bacterial flora of the gastrointestinal tract in healthy and achlorhydric persons. Gastroenterology $56: 71$ (1969).

5. EDITORIAL: Classification of infantile malnutrition. Lancet ii : 302 (1970),

6. ELLIOTT, R.B., M. GRACEY, J. THOMAS AND D.E. STONES: Influence of intestinal micro-organisms on intestinal sugar absorption. Austr. Paediatr. J. 8 : 224 (1972) (abstr.).

7. GORBACH, S.L., J.G. BANWIELL, B. JACOBS, B.D. CHATTERJEE, R. MITRA, N.N. SEN AND D.N. GUHA MAZUMDER: Tropical sprue and malnutrition in West Bengal. I. Intestinal microflora and absorption. A.m. J. clin Nutr. 23 : 1545 (1970).

8. GORBACH, S.L., J.G. BANWELL, R. MITRA, B.D. CHATERJEE, B. JACOBS AND D.N. GUHA MAZUMDER: Bacterial contamination of the upper small bowel in tropical sprue. Lancet $i$ : 74 (1969).

9. GRACEY, M. AND D.E. STONE : Small intestimalmicroflora in Australian aboriginal children with chronic diarrhoea. Austr. N.Z.J. Med. 3: 215 (1972).
10. IVESON, J.B., AND E.M. MACKAYSCOLLAY: Strontium chloride and selenite enrichment broth media in the isolation of Salmonella. J. Hyg. (Cambridge) $67: 457$ (1969).

11. IVESON, J.B., E.M. MACKAY- SCOLLAY AND V.V. BAMFORD: Salmonella and arizona in reptiles and man In Western Australia. J. Hyg. (Cam. bridge) $67: 135$ (1969).

12. JAMES, W.P.T., B.S. DRASAR AND C MILLER: Physiological mechanism and pathogenesis of weanling diarrhea. Am. J. clin Nutr. 25: 564 (1972).

13. JELIIFFE, D.B.: The assessment of the nutritional status of the community. WHO. Monogr. Ser. No. 53 Geneva (1966)

14. KING, S., AND W.I. METZGER: A new plating medium for the isolation. of enteric pathogens. Appl. Microbiol. 16 : 577 (1968).

15. MATA, L.J., F. JIMENEZ, M. CORDON, R. ROSALES, E. PRERA, R.E. SCHNEIDER AND F, VITERI; Gastrointestinal flora of children with protein-calorie malnutritions. Am. J. clin Nutr. 25: 1118 (1972).

16. SCRIMSHAW, N.S. C.E. TAYLOR AND J.E. GORDON; Interactions of Nutrition and Infection. WHO. Monogr. Ser. No. 57 Geneva (1968).

17. SOKAL, R.R., AND F.J. ROHLF: Biometry, the Principles and Practice of Statistics in Biological Research. p. 382 (Freeman, San Francisco 1969).

18. TUMBELLAKA. W.A.F.J.: Aspects of Paediatric gastroenterology in Indonesia, Proc. 3rd Asian Pasific Congr. Gastroenterology p. 153 Melbourne, Australia (1968). 